\title{
Settlement of the Early Linear Ceramics Culture at Brunn am Gebirge, Wolfholz site
}

\author{
Peter Stadler \\ Museum of Natural History \& University of Vienna, Austria \\ Peter.Stadler@univie.ac.at
}

\begin{abstract}
The early Neolithic sites I to V from Brunn Wolfholz, south of Vienna, were excavated between 1989 and 2005. Till now about 75 longhouses, with the standardized size of $20 \times 7 \mathrm{~m}$ have been recognized. The whole settlement has a length from North to South of $850 \mathrm{~m}$ and from East to West of $500 \mathrm{~m}$. The oldest part is site IIa in the south; it contains rough ceramics with plastic ornaments, which seem to be in a Starčevo tradition. The Early Linear Ceramics starts only in site III. The youngest phase of the settlement is in the North in site I, which apparently leads already to the Notenkopf Ceramics.

IZVLEČEK - V letih 1989 do 2005 so v Brunn Wolfholzu, južno od Dunaja, potekala izkopavanja na zgodnjeneolitskih najdiščih I do V. Do sedaj so na najdiščih odkrili okoli 75 hiš s standardnimi merami $20 x 7 \mathrm{~m}$. Celotno najdišče meri od severa proti jugu $850 \mathrm{~m}$ in od vzhoda proti zahodu $500 \mathrm{~m}$. Najstarejši del je najdišč IIa na jugu; tam so našli grobo okrašeno keramiko, ki verjetno sodi v kulturo Starčevo. Zgodnja LTK se pojavlja šele na najdišču III. Najmlajša faza poselitve je razvidna na severu, na najdišč I in očitno predstavlja prehod $k$ fazi 'notenknopf' keramike.
\end{abstract}

KEY WORDS - Starčevo; Linear ceramics; settlement; longhouses; stone implements

Between 1989 and 2005 at Brunn am Gebirge, Lower Austria, on the southern edge of Vienna (see map in Figure 1), parts of a large early Neolithic settlement were surveyed and excavated. Two aerial photos give an overview of the excavations in 1992 and 1999 (see Figs. 2 and 3). Some internet publications and articles with preliminary reports have been published (Stadler 1997; Lenneis, Stadler and Windl 1996.97-116; Sauter et al. 2002.54-60; Lenneis 2001.105-106, Fig. 8). Currently a book concerning the ceramics from Brunn Wolfholz is in preparation (Stadler in press).

The terrain is flat and has a slight rise to the northeast. The remains of longhouses found belong to at least five different, separated groups, which were called sites I-V. Seventy-five longhouses are known, most of them by excavation, some only after their destruction by trenches and a large number by geo- physical survey. As the whole area has not been surveyed, a total of some 100 houses are expected. The excavated area is about $100000 \mathrm{~m}^{2}$. (See excavation map in Figure 5)

The houses are usually oriented south-north, with deviations to the west and east at different sites. Their dimensions are $20 \mathrm{~m}$ long and 7-8 $\mathrm{m}$ wide. Details of some houses are visible in Figures 2 and 3. Different constructions are visible, mainly in the better preserved part of site III. Whether these differences are functional or chronological is still under investigation. Over the excavated area we have reconstructed 8 longhouses in Figure 4.

Currently we see the absolute time frame between $5540-5060 \mathrm{BC}$ on the $1 \sigma$-level for the whole settlement because of 60 AMS radiocarbon dates measured at Zurich at the ETH and at the Vienna VERA-lab. 
The oldest part of the settlement may be site IIa, followed by IIb, III, IV, I and V. We are aware that this time range (especially on the older side) may be too old, because most of our samples were charcoals from oak wood, thus the old wood effect could play some role.

\begin{tabular}{lccc} 
Site & $\begin{array}{c}\text { Number } \\
\text { of samples }\end{array}$ & $\begin{array}{c}1 \sigma \text { range } \\
\text { BC }\end{array}$ & $\begin{array}{c}\mathbf{2} \sigma \text { range } \\
\text { BC }\end{array}$ \\
\hline $\mathrm{IIa}$ & 12 & $5540-5210$ & $5750-5050$ \\
\hline $\mathrm{IIb}$ & 14 & $5480-5280$ & $5650-5050$ \\
\hline $\mathrm{III}$ & 24 & $5450-5200$ & $5700-4950$ \\
\hline $\mathrm{IV}$ & 5 & $5390-5300$ & $5480-5200$ \\
\hline $\mathrm{I}$ & 4 & $5310-5060$ & $5370-4940$ \\
\hline $\mathrm{V}$ & 1 & $5305-5255$ & $5320-5200$ \\
\hline Total & 60 & $5480-5060$ & $5700-5000$
\end{tabular}

In the oldest parts, Linear Ceramic is missing; the rough ceramic was fired at lower temperatures and has none, or at least only plastic ornamentation. Shards of this ceramics can be seen in Figures 7 and 8. This type of ceramic is very similar to that from excavations in Southern Hungary attributed to the Late Starčevo Culture, for example at GellénházaVárosrét (Simon 2001).

From site III the rise upwards to the younger parts of the settlement Linear Ceramics increases, which is paralleled by the increasing use of fine ceramics beside the coarse varieties. On the other hand, the number of idols found decreases. Such ceramic are presented in Figures 9 and 10.

Currently, for the book mentioned above, we installed the "Montelius" image database for the ceramics and set up a typology for it with help of Michaela Lochner (in press) and Eva Lenneis (in press). All ceramic features are mapped on the excavation map, and by means of statistics it is decided which maps are non-random. One of these maps is seen in Figure 11. All these non-random maps are evaluated together by our method of "Analysis of the N Next Neighbours". This analysis tries to find a combination map for all other mappings. The result is presented in Figure 12. To better understand which relations exist between pits containing the same features we can show the result with a network plan in Figure 13. All relations can be seen as lines between the pits containing the same features; the line width corresponds with the number of different relations.

The ceramics from Brunn and its different sites were analysed petrographically and chemically by Roman
Sauer (in press), who has shown that all the ceramics were produced with local clay.

For the stone implements also a development is visible in the same direction, from the earliest site II, to the most recent, site I. Of special interest is that we found many stone implements, more than 10000 , most in the oldest site II. Some of the trapezes found there are shown in Figure 14. The large quantity of lithic material is very much in contrast to other Austrian sites.

At the beginning, the principle raw material came from Bakony-Szentgál, near Lake Balaton in Hungary. Local "Hornstein" was very seldom used. These percentages change continuously from early to late. At the end of the development in site I, we have only a small number of local lithic material at all. The lithic material from Brunn has been analysed in two preliminary publications (Gronenborn 1997.60-61; Mateiciucova 2002.169-188).

Animal bones are not preserved in large numbers at site II. This may not depend on bad bone preservation on this site, because human skeletons were found in four graves at site II (Gerold and TeschlerNicola, in press). But we can also see a development in the usage of animals over the course of time. In site III it seems that capra-ovis bones dominate, and in the most recent site I bovis was preferred. The animal bones investigations were done by Erich $\mathrm{Pu}$ cher (1998; in press).

So we see that there was a big change in the course of time at the Brunn Wolfholz sites. The most interesting question now is: did the settlers come from southern Hungary or is there a local change from a Mesolithic population to the first farmers under influences from the south?

As we have almost no knowledge about Mesolithic sites in Lower Austria, we tend currently to the first solution - that settlers immigrated from Southern Hungary and formed at Brunn am Gebirge a base for the development of the Linear Ceramics culture. 


\section{REFERENCES}

GEROLD F. and TESCHLER-NICOLA M., in press. Die menschlichen Skelettreste aus der frühneolithischen Siedlung von Brunn am Gebirge. in press. Die Erfassung der Keramik. In P. Stadler (ed.), Die Keramik aus der frühneolithischen Siedlung von Brunn am Gebirge, aus dem Grabungsjahren 1989 bis 1993. Mit Beiträgen zu Anthropologie, Zoologie und Botanik.

GRONENBORN D. 1997. Silexartefakte der ältestbandkeramischen Kultur. Universitätsforschungen zur Prähistorischen Archäologie. Aus dem Seminar für Vor- und Frühgeschichte der Universität Frankfurt/M. Band 37.

LENNEIS E. 2001. The Beginnings of the Neolithic in Austria - a report on recent and current investigations. In M. Budja (ed.), 8th Neolithic Studies, Documenta Praehistorica XXVIII: 99-116.

in press. Zu einigen wesentlichen Merkmalen der Keramik von Brunn. In P. Stadler (ed.), Die Keramik aus der frühneolithischen Siedlung von Brunn am Gebirge, aus dem Grabungsjahren 1989 bis 1993. Mit Beiträgen zu Anthropologie, Zoologie und Botanik.

LENNEIS E., STADLER P. and WINDL 1996. Neue 14CDaten zum Frühneolithikum in Österreich. Prehistoire Européenne 8: 97-116.

LOCHNER M., in press. Die Erfassung der Keramik. In P. Stadler (ed.), Die Keramik aus der frühneolithischen Siedlung von Brunn am Gebirge, aus dem Grabungsjahren 1989 bis 1993. Mit Beiträgen zu Anthropologie, Zoologie und Botanik.

MATEICIUCOVA I. 2002. Silexartefakte der ältesten und älteren Linearbandkeramik aus Brunn am Gebirge, Niederösterreich (Vorbericht). Antaeus 25: 169-188.

PUCHER E. 1998. Die Tierknochen des linearbandkeramischen Siedlungsplatzes Brunn am Gebirge (Niederösterreich). In P. Anreiter, L. Bartosiewicz, E. Jerem and W. Meid (eds.), Man and the Animal World. Studies in Archaeo-zoology, Archaeology, Anthro- pology and Palaeo-linguistics: in memoriam Sándor Bökönyi. 465-479.

in press. Die Tierknochen der Fundstellen von Brunn.

in press. Die Erfassung der Keramik. In P. Stadler (ed.), Die Keramik aus der frühneolithischen Siedlung von Brunn am Gebirge, aus dem Grabungsjahren 1989 bis 1993. Mit Beiträgen zu Anthropologie, Zoologie und Botanik.

SAUTER F., VARMUZA K., WERTHER W. and STADLER P. 2002, Chemical Analysis of organic material found in traces on a neolithic terracotta idol statuette excavated in Lower Austria. Studies in Organic Archaeometry V. ARKIVOC 2002 (i) 54-60. http://www. arkatusa.org/ark/journal/2002/General/1-343E/ 343E.pdf

SIMON K. 2001 Die neolithischen Fundes des Objektes 103/96 von Gellénháza-Városrét (Komitat Zala). Zalai Múzeum 10: 19-43.

STADLER P. 1997. Die Homepage der Archäologischen Ausgrabung einer Frühneolithischen Siedlung von Brunn am Gebirge, Flur Wolfsholz (6. Jahrtausend v. Chr.). Online http://www.nhm-wien. ac.at/ nhm/Prehist/Stadler/Brunn/Brunn_g.html

2005. Quantitative Studien zur Archäologie der Awaren. Mitteilungen der Prähistorischen Kommission Österreichische Akademie der Wissenschaften 60. Verlag der Österreichischen Akademie der Wissenschaften

in press. Die Keramik aus der frühneolithischen Siedlung von Brunn am Gebirge, aus dem Grabungsjahren 1989 bis 1993. Mit Beiträgen zu Anthropologie, Zoologie und Botanik.

SAUER R., in press. Petrographische und mineralogische Untersuchungen an Keramikproben und Sedimentproben. in press. Die Erfassung der Keramik. In P. Stadler (ed.), Die Keramik aus der frühneolithischen Siedlung von Brunn am Gebirge, aus dem Grabungsjahren 1989 bis 1993. Mit Beiträgen zu Anthropologie, Zoologie und Botanik. 


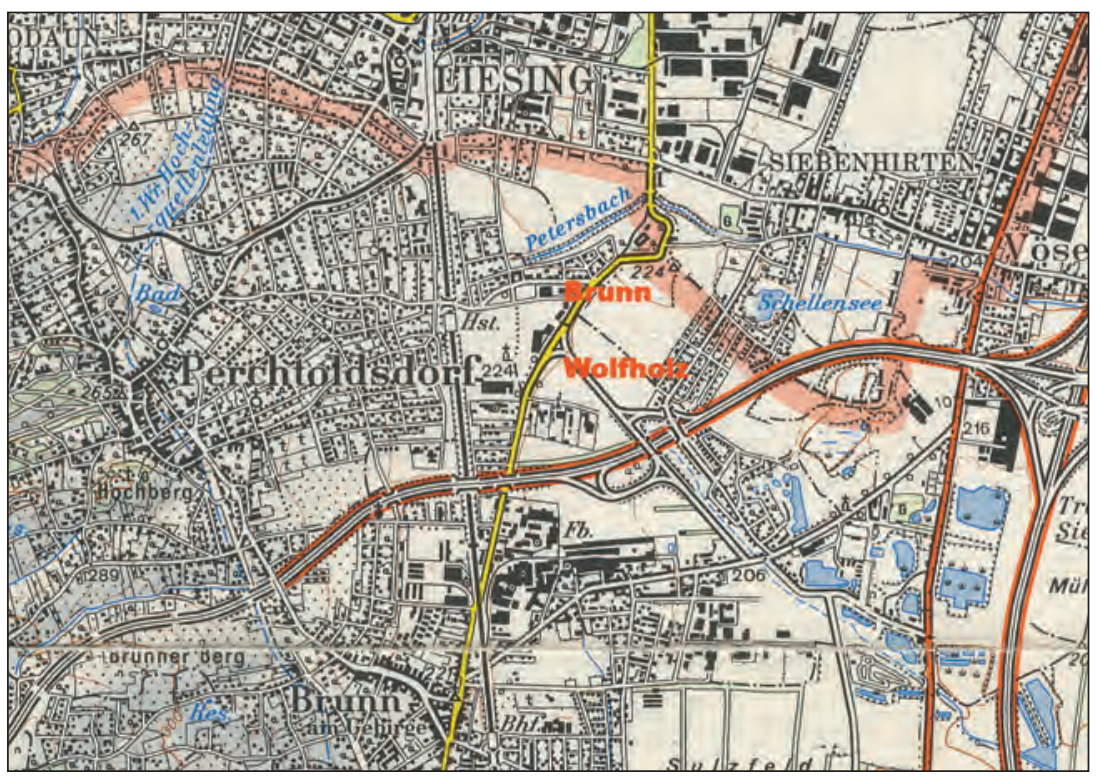

Fig. 1. Localization of Brunn Wolfholz on the city map of Vienna.

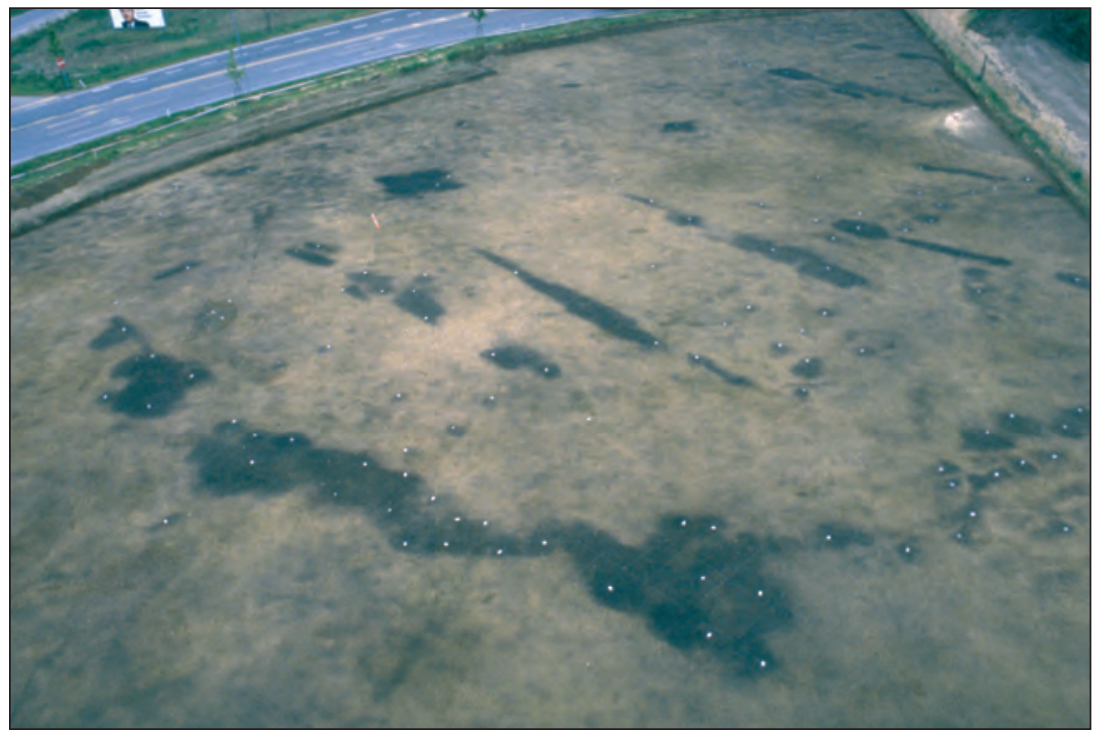

Fig. 2. Brunn-Wolfholz Excavation 1992, aerial photo of the ground plan of 5 longhouses.

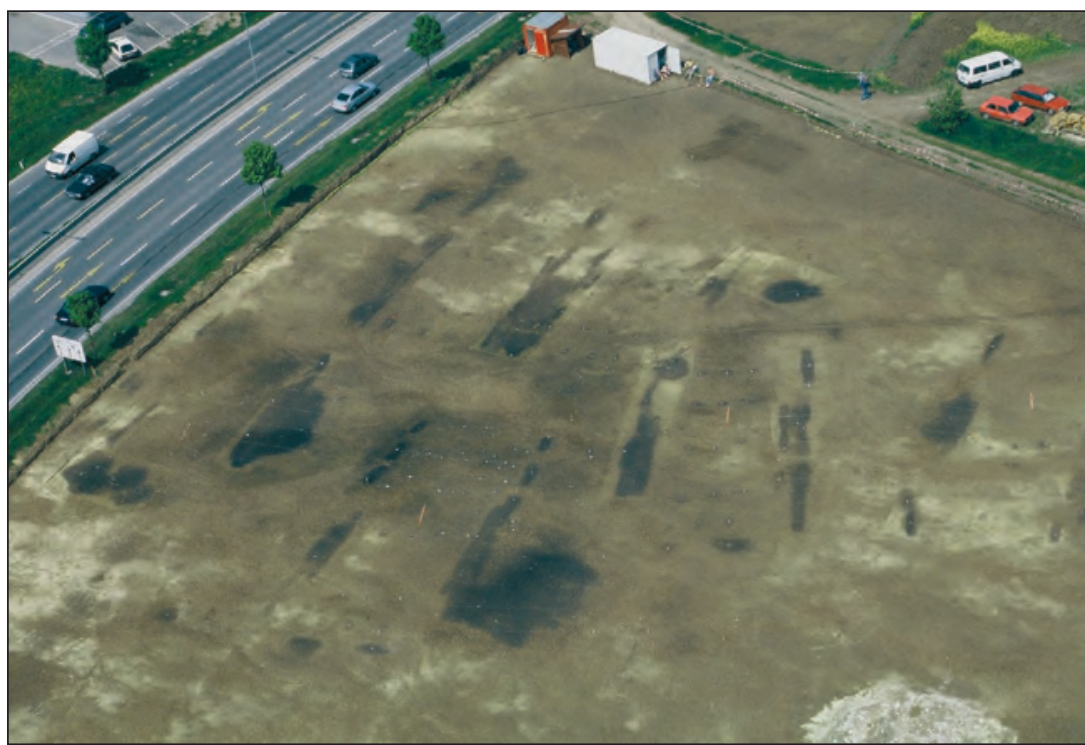

Fig. 3. Brunn-Wolfholz Excavation 1999, aerial photo of the ground plan of 5 longhouses. 
Fig. 4. Reconstruction of eight long-houses above their foundations on the air-photo of the excavation 1992 on site II from Brunn Wolfholz.
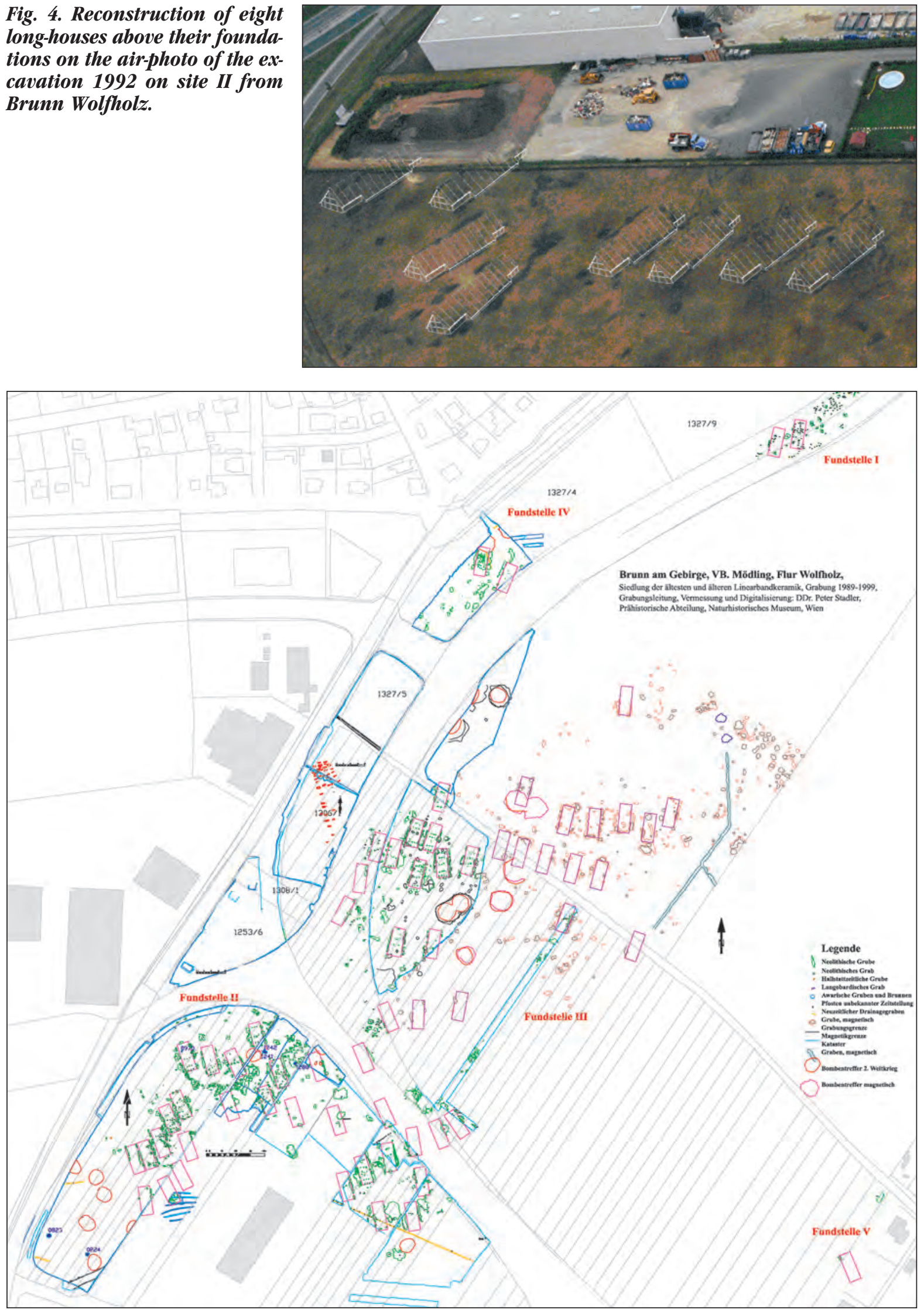

Fig. 5. Map of the excavation of the Oldest Linear Ceramics settlement from Brunn am Gebirge/Wolfholz. Till now five sites (I-V) have been identified. The houses are symbolized by the rectangle put over the pits belonging to one house. 


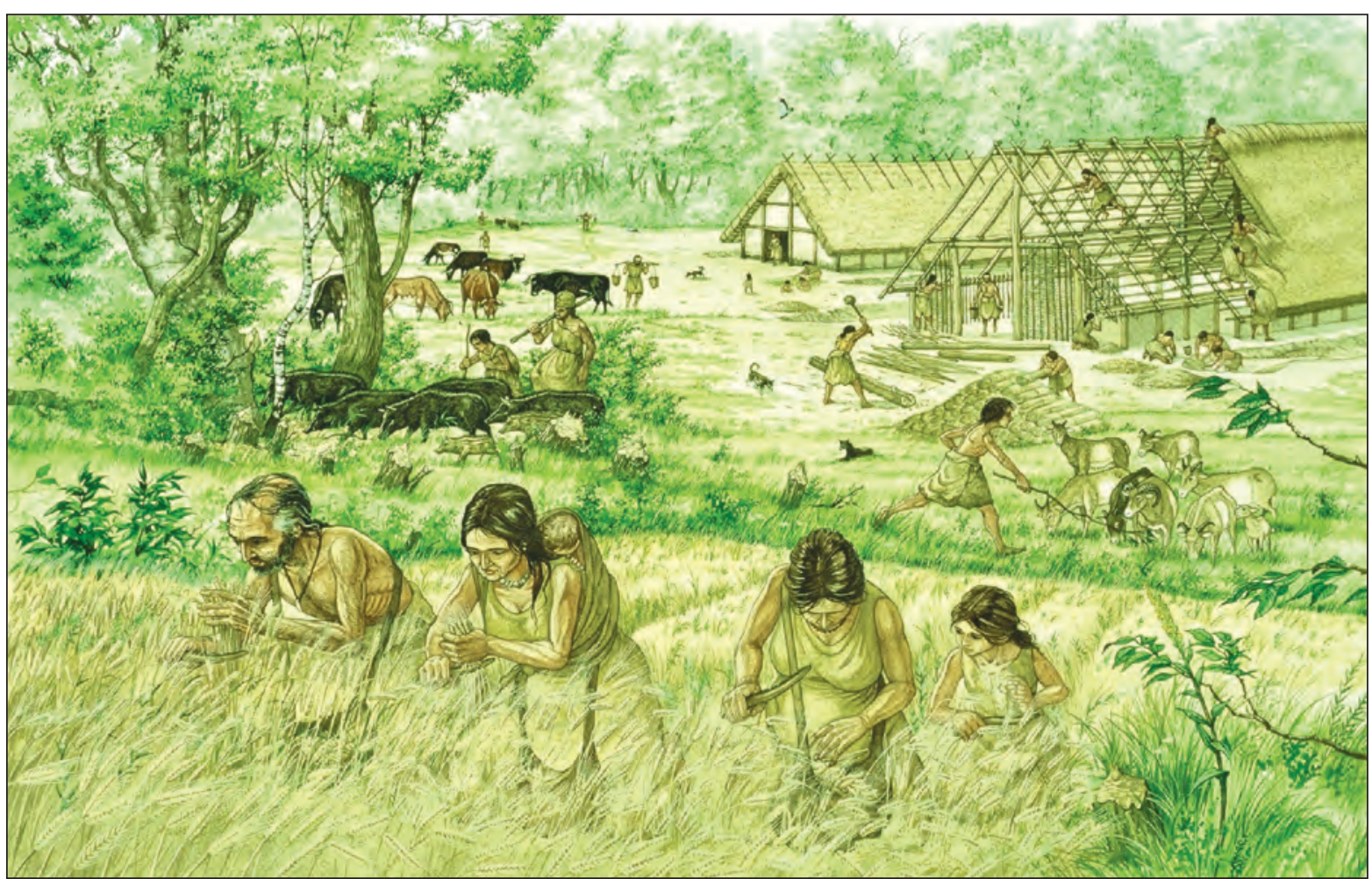

Fig. 6. Reconstruction of every day's life at site of Brunn Wolfholz. Dominic Groebner (C) Prähistorische Abteilung, Naturhistorisches Museum Wien.

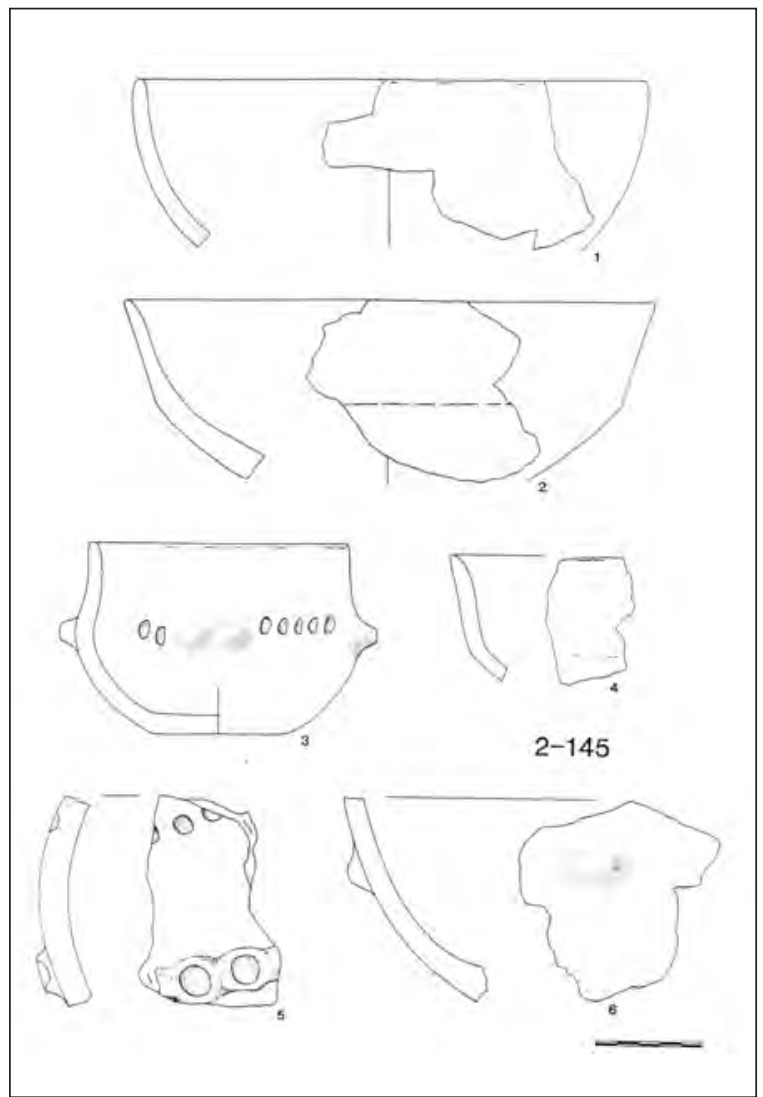

Fig. 7. Ceramics from the oldest site II of the Oldest Linear Ceramics settlement from Brunn am Gebirge/Wolfholz.

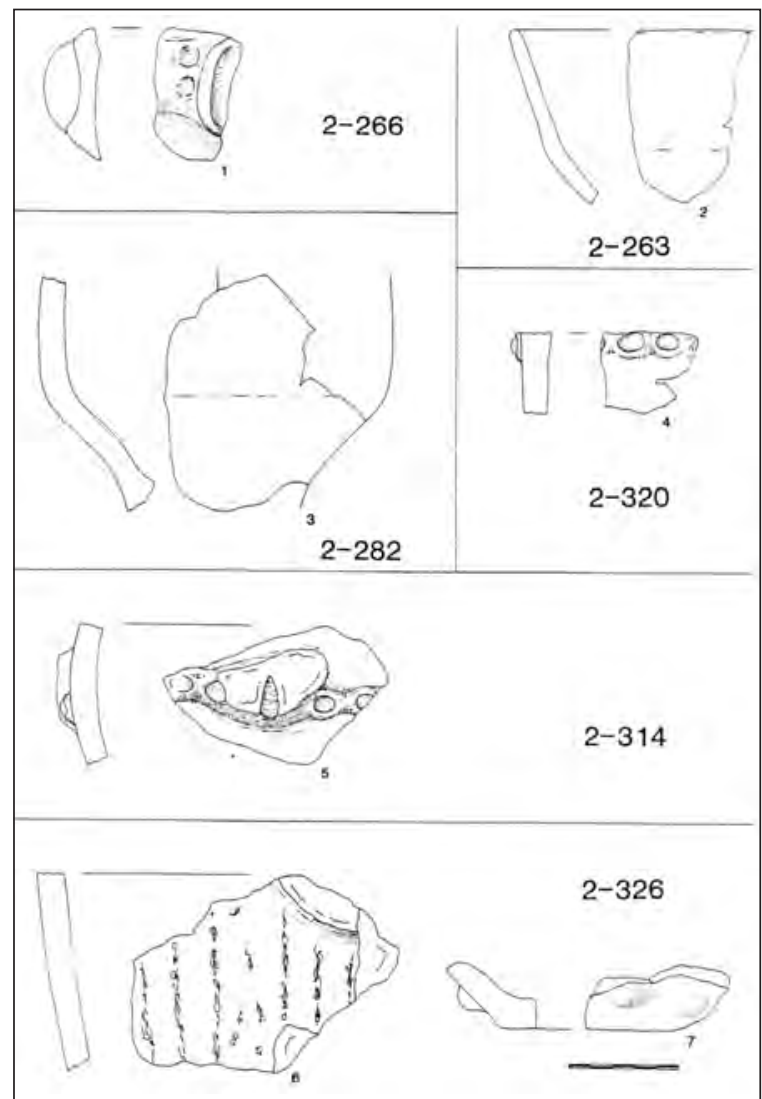

Fig. 8. Ceramics from the oldest site II of the Oldest Linear Ceramics settlement from Brunn am Gebirge/Wolfholz. Wolfholz. 


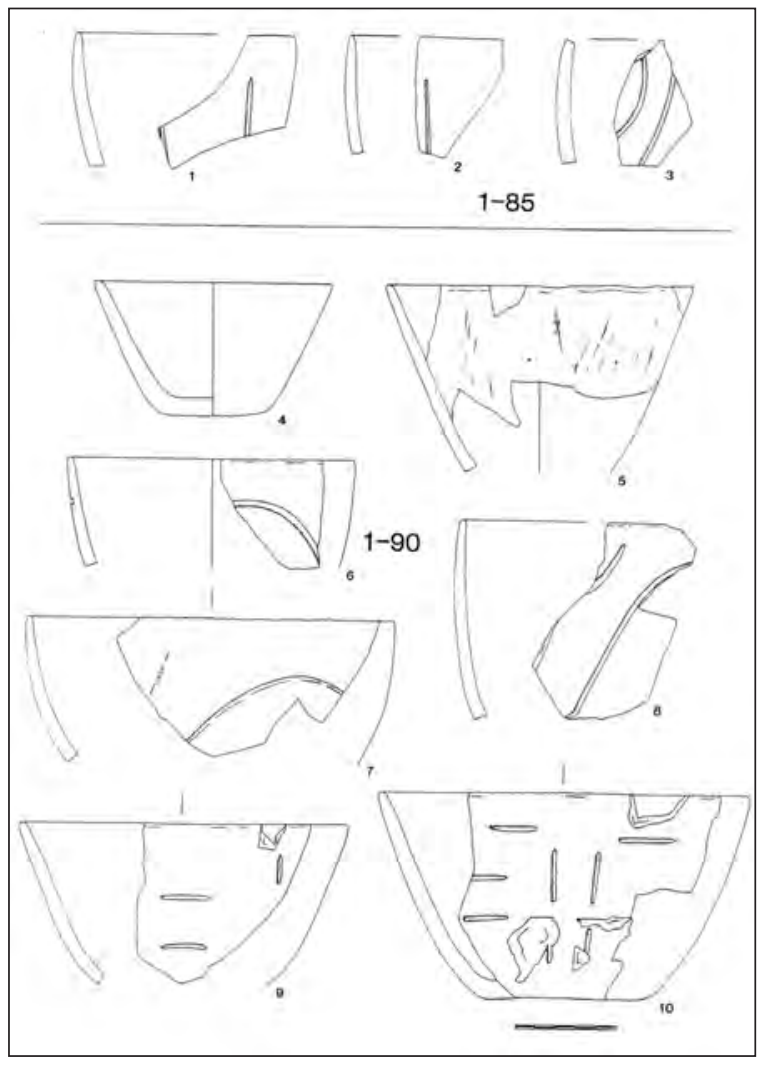

Fig. 9. Ceramics from the youngest site I of the $\mathrm{Ol}$ dest Linear Ceramics settlement from Brunn am Gebirge/ Wolfholz.

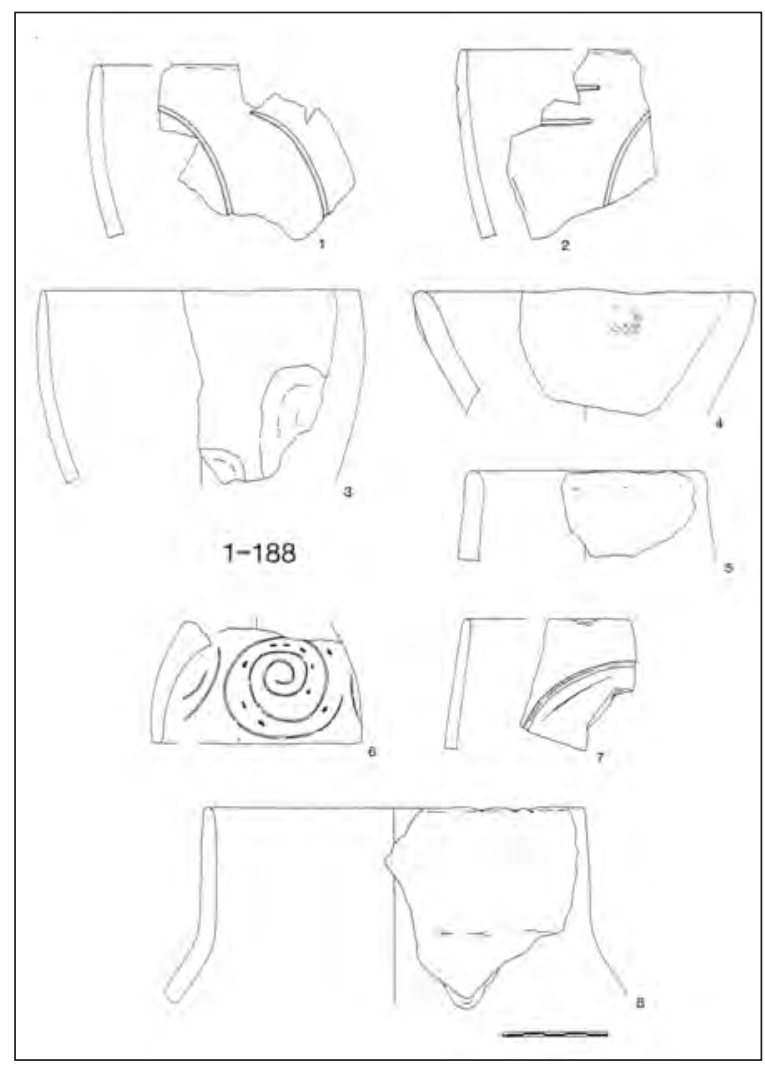

Fig. 10. Ceramics from the youngest site I of the $\mathrm{Ol}$ dest Linear Ceramics settlement from Brunn am Gebirge/Wolfholz.

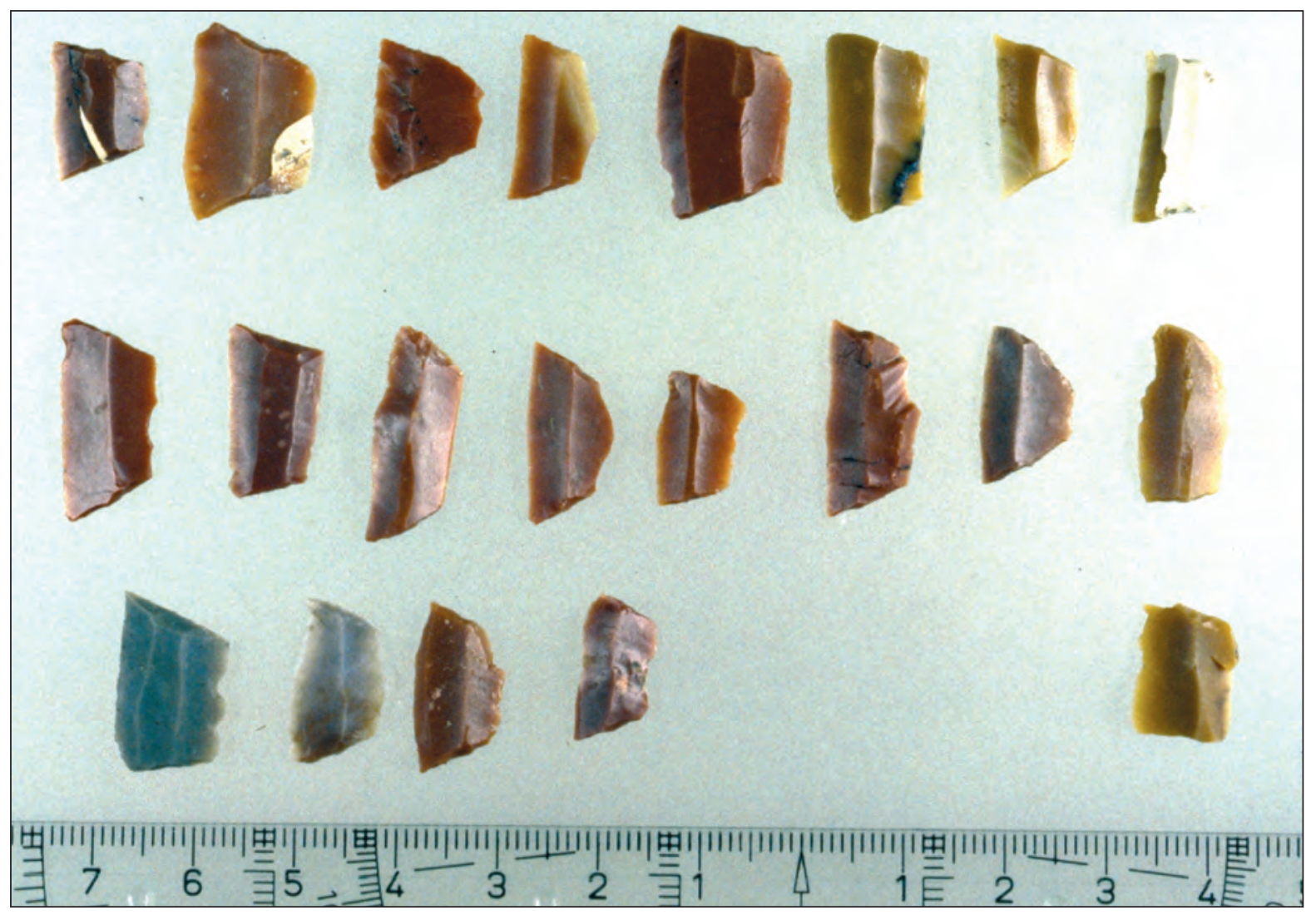

Fig. 14. Lithic material from site II in form of trapezes. 
aktuelle Parameter:NextNeiN $=20$ KonfNivN=3 Normkoor $=0$ Frequ $=0$ n

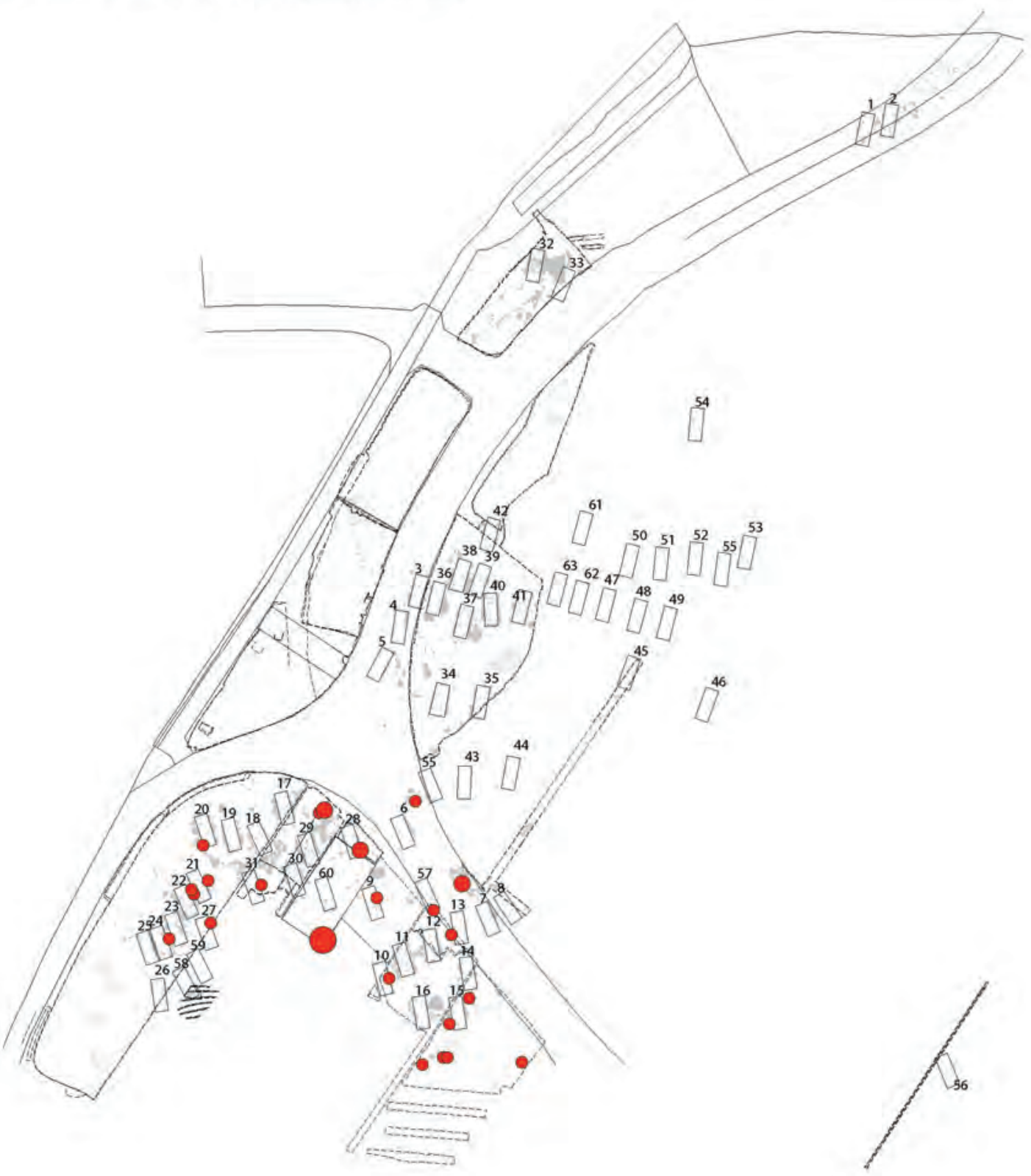

Fingertupfenleiste00010 : Fingertupfenleiste/mit Knubben/am größten Bauchdurchmesser/ $\mathrm{N}=23$ [ 30], wirklicher $\mathrm{M} . \mathrm{w} .=0.63$, erwarteter $\mathrm{M} . \mathrm{w} .=0.32$, Differenz $=0.32$, Konfidenzniveau $=100.0 \%$

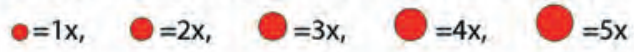

Fig. 11. Mapping of ceramic feature „Fingertupfenleiste00010“ on the site map. Wolfholz. 


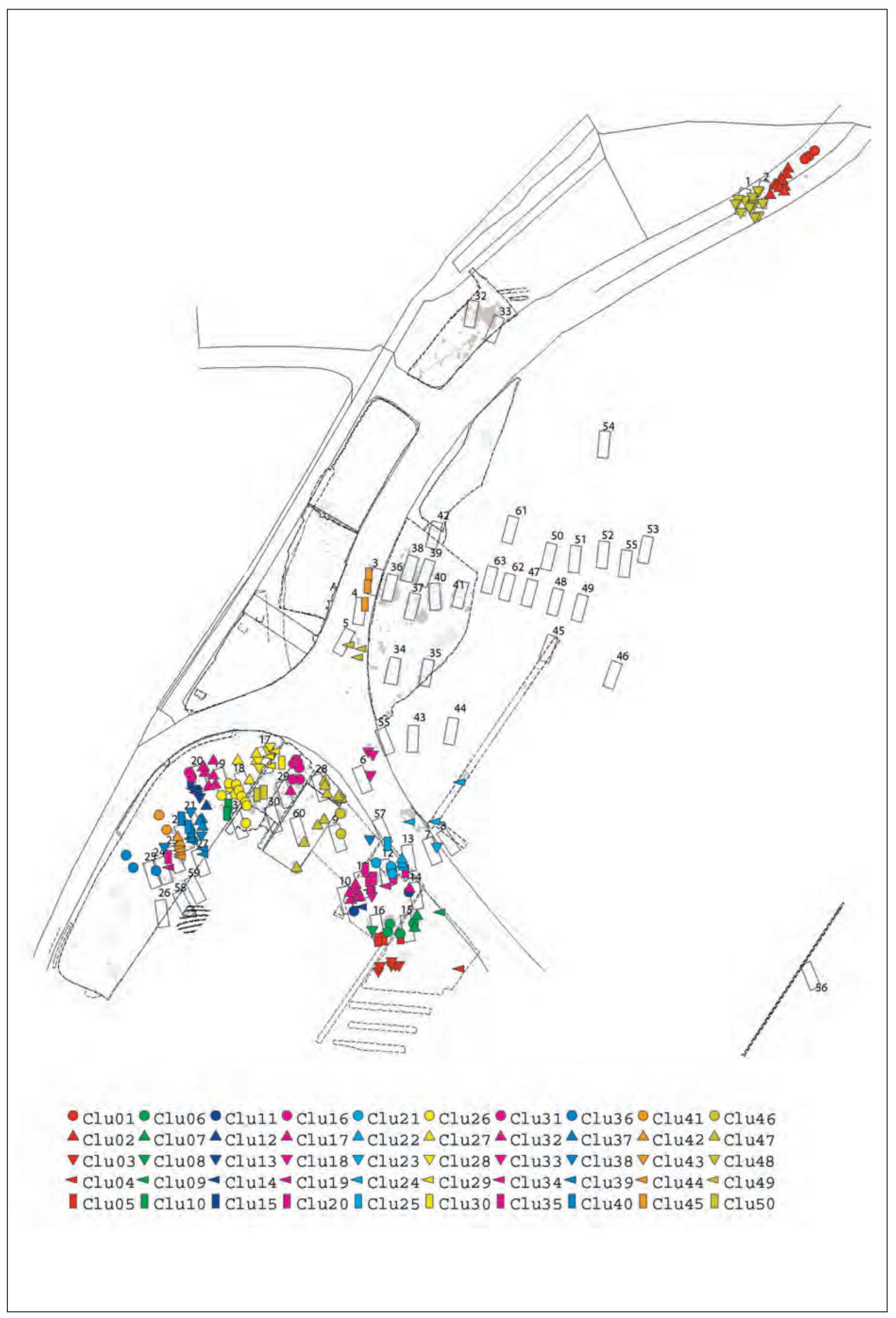

Fig. 12. „Analysis of the N Next Neighbours“ with ceramics features, Site of Brunn Wolfholz. 


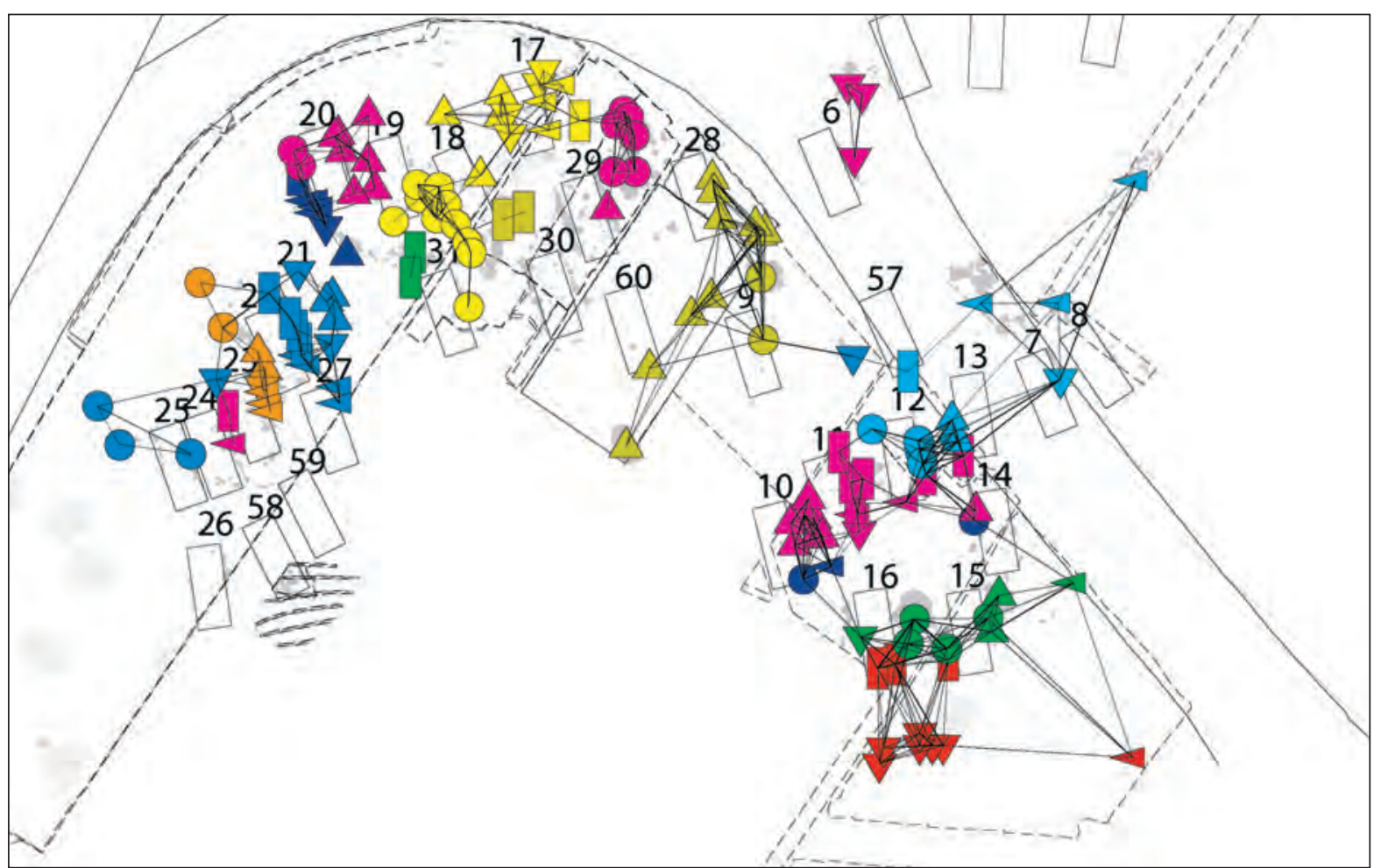

Fig. 13. Network sketch of „Analysis of the N Next Neighbours" with ceramics features, clipping of site II. 